\title{
Biochemical composition of tropical eel Anguilla bicolor McClelland,1844 in Freshwater and Estuary
}

\author{
Farida Nur Rachmawati ${ }^{1 *}$, Untung Susilo ${ }^{1}$ \\ ${ }^{1}$ Faculty of Biology, Jenderal Soedirman University. Jl. Dr Soeparno No 63 Purwokerto 53123, \\ Central Java, Indonesia.
}

\begin{abstract}
During migration, Anguilla bicolor will stop its feeding activity and use energy from its body lipid stores. Therefore, information on changes in the body lipid content of eels is essential to know the preparation of spawning migration. Thus, it is interesting to study the body composition of A. bicolor in freshwater and estuaries. This research conducted a survey method. The eel was obtained from the Serayu River (freshwaters) and Segara Anakan (Estuary). The observed variables were water, dry weight, lipid, protein, crude fiber, ash, and BETN of eel. Oneway ANOVA analyzed data. The results show that freshwater eels' average body length and weight were $457.875 \mathrm{~cm} \pm 153.8552$ and $224.4375 \mathrm{~g} \pm$ 165.3735. The body length and weight of the estuary eels were smaller than freshwater eels, which are $372.5714 \mathrm{~cm} \pm 152.6467$ and $109.6429 \mathrm{~g} \pm$ 134.6054, respectively. The body composition of eel, except for lipid content, was similar for both habitats $(\mathrm{p}>0.05)$. However, the body lipid content of freshwater eels and the estuarine eel differed $(\mathrm{p}<0.05)$, namely $40.15 \% \pm 9.63$ and $27.33 \% \pm 9.93$, respectively. In conclusion, the lipid body content of freshwater eels was higher than the estuary eel, while another is relatively the same.
\end{abstract}

\section{Introduction}

Anguilla sp. is catadromous, which during the life phase is in two different habitats. Juvenile eel (immature) and silver eel live in freshwater, and silver eel lives in an estuary at spawning. They in freshwaters will migrate to the sea during the growth phase through estuarine habitats (brackish water). The life cycle of the eel starts from leptocephalus, which will subsequently metamorphose into glass eels. Leptocephalus living in the sea metamorphoses into glass eels, ready to migrate from seawater to freshwater to mature (silver eel), then the eel will migrate back to the sea to spawn [1-7]. In general, small-sized eel fish like shallow waters with abundant aquatic plants, large fish are found in the medium and deep ocean with tiny aquatic plants [8].

Overfishing, ecological damage, and other factors such as the presence of reservoirs resulted in a decrease in the eel population in the world, such as $A$. anguilla and $A$.

\footnotetext{
* Corresponding Author : farida.rachmawati@unsoed.ac.id
} 
japonica. [9-11]. The eel population's reduction is not accompanied by increased cultivation productivity because eel is challenging to mature in aquaculture conditions. Therefore, information about the reproductive character of the eel is essential as a basis for spurring the maturity of the gonad in aquaculture conditions [12-14].

Increasing lipid content of eel is one of the indicators for gonad maturity. Lipid is a source of energy during migration to sea waters for spawning and is a vitellogenin precursor in the preparation of female reproduction [15]. Juvenile eels (yellow eels) will be ready to migrate to undergo the silvering process (prepubertal) when their body lipid content reaches $>20 \%$, but sometimes eels prefer to remain in freshwaters [16].

Information about the migration patterns of eels, especially A. bicolor, is not yet available, so it is interesting to study the biochemical content of the body of $A$. bicolor in freshwater and estuarine.

Previous studies found that the male $A$. rostrata and $A$. japonica are in freshwater and estuarine. At the same time, female eel is found only in freshwater, also stated that the male would complete its gametogenesis process at sea. Thus, the male is rarely in freshwater because they prefer to live in the estuarine, as found in A. rostrata and A. japonica $[9,15$, 17].

As migratory animals, generally, change in salinity from freshwater to marine waters will stimulate gonad maturity. So, the observation of the reproductive character of male eels in freshwater and estuarine is interesting to study. This information is essential to know the process of maturity of gonad eel in both habitats. There are freshwater eel fish and estuaries, so their presence in different habitats is not due to migration but through a phase of growth in freshwater and estuarine habitats.

Therefore, observing eel fish's body composition in both habitats is interesting because it will migrate when it reaches maturity gonad and has a body lipid content of $>20 \%$ [5]. Related information body composition of $A$. bicolor eel during the gonad maturity process until now is not available. Thus it is necessary to study the body composition of tropical eel Anguilla bicolor in different habitats.

\section{Materials and Methods}

The method used in this study is a survey method with random sampling. A total of 44 eels were obtained from fishers in the Serayu River (freshwaters) and the Segara Anakan (Estuary). The eel is taken to the Laboratory of Animal Physiology using an open transportation system. Furthermore, the fish is accommodated in a fiber aquarium $(2 \times 3 \times 1$ $\mathrm{m}^{3}$ ) and satisfied $1 \times 24$ hours (during data retrieval). Fish were acclimatized for one day before surgery for morphological and physiological observations. The observed variables were the body composition of eel, which included: water content, dry weight, lipid, protein, crude fiber, ash, and BETN (Nitrogen Free Extract Ingredients). Besides body composition, as supporting data, observed sex ratio and GSI value of eel.

\subsection{Measurements of body length and body weight}

Measurements of body length and weight are carried out after the fish is unconscious to reduce movement. Fish are sedated using eugenol at a dose of $5 \mathrm{ppm}$ for 30 minutes until fainting [14]. The body weight was measured using a technical scale, while body length was measured using a ruler. The measured body length is the total body length from the head's tip to the tail's end.

The developmental stage of the eel can be determined by observing the colour of the abdominal part of the body. Yellow eel stadia eel (juvenile) has yellow abdominal skin, and silver eel stadia eel has silver [18]. 


\subsection{Gonad Isolation}

Eel fish are dissected to be isolated gonads using surgical devices. Gonads are weighted using analytical scales (Explorer O-HAUS) to calculate the value of GSI (Gonadosomatic Index) according to [19].

$$
G S I=\left(\frac{\text { gonad weight }}{\text { bodv weight }}\right) \times 100 \%
$$

\subsection{Preparation of Proximate Analyses}

The body of the eel without visceral organs is divided into three parts. The abdomen, onethird of the body, is placed on a petri dish and then covered with aluminum foil. The sample is put in the oven at $60^{\circ} \mathrm{C}$ until dry. Then, the fish were proximate analyses at the Laboratory of Nutrition Science, Faculty of Animal Science, UNSOED.

\subsection{Measurement of Sex Ratio}

The measurement of Sex Ratio refers to [20] with the following formula:

$$
\mathrm{SR}=\frac{\mathrm{NF}}{\mathrm{NM}}
$$

$\mathrm{SR}=$ Sex ratio, $\mathrm{NF}=$ Number of females, $\mathrm{NM}=$ Number of males

\subsection{Data analysis}

The quantitative data obtained were analyzed by one-way analysis of variance (One Way ANOVA) [21].

\section{Results}

Female A. bicolor is more dominant caught in freshwater than in an estuary. The result shows that females dominate freshwater catch at $62.5 \%$, while the remaining $37.5 \%$ are eel with gonads undifferentiated. In estuarine, the sex ratio is $32 \%$ females: $43 \%$ males, and the remaining $25 \%$ are gonads undifferentiated.

The body composition of eel in freshwater, especially lipid, is significantly higher than an eel in an estuary $(\mathrm{p}<0.05)$ (Table 1$)$. The lipid content of $A$. bicolor was quite different $(\mathrm{p}<0.05)$ in the two habitats. Freshwater A. bicolor is higher than estuary A. bicolor. The lipid content of Freshwater A. bicolor is $40.15 \pm 9.63 \%$, and estuary A. bicolor is $27,33 \pm$ 9,93. A significant difference between the two habitats indicates that the eels that live in fresh waters are ready to migrate, while the eel in the estuary is still not.

Table 1. The body composition of Anguilla bicolor McClelland, 1884 in different habitats

\begin{tabular}{|l|c|c|}
\hline Body Composition (\%) & Freshwater & Estuary \\
\hline Water & $3.92 \pm 0.49^{\mathrm{a}}$ & $5.18 \pm 0.75^{\mathrm{a}}$ \\
\hline Dry Weight & $96.08 \pm 0.49^{\mathrm{a}}$ & $94.82 \pm 0.75^{\mathrm{a}}$ \\
\hline Protein & $48.85 \pm 7.08^{\mathrm{a}}$ & $55.46 \pm 6.91^{\mathrm{a}}$ \\
\hline Lipid & $40.15 \pm 9.63^{\mathrm{b}}$ & $27.33 \pm 9.93^{\mathrm{a}}$ \\
\hline Crude Fibre & $1.64 \pm 1.36^{\mathrm{a}}$ & $1.96 \pm 1.51^{\mathrm{a}}$ \\
\hline Ash & $5.21 \pm 1.29^{\mathrm{a}}$ & $6.67 \pm 1.51^{\mathrm{a}}$ \\
\hline BETN (Nitrogen Free Extract Ingredients) & $4.15 \pm 2.93^{\mathrm{a}}$ & $8.58 \pm 4.34^{\mathrm{a}}$ \\
\hline
\end{tabular}

BETN: Nitrogen-Free Extract Ingredients 
The reproductive parameters include, GSI is higher in freshwater eel than estuarine $(\mathrm{p}<0.05$; Table 1$)$. This study showed that the developmental stadia, body length, and habitat influence the value of GSI. Freshwater $A$. bicolor has a GSI value greater than estuarine [37]. The value of GSI A. bicolor caught in freshwater varies but generally still below 5\%, which is $1.04-2.96 \%$ [35]; $0.1-2.88 \%$ [13] and $0.03-4.37 \%$ [22].

\section{Discussions}

\subsection{Sex Ratio}

Female A. bicolor is more dominant caught in freshwater than an estuary; the results of this study are the same as the observations of [12] and [23]. Female of A. bicolor has a $100 \%$ dominant catch in Segara Anakan [12]. In contrast, in Peninsular Malaysia, 73\% females, $13 \%$ of males, and $14 \%$ of gonads undifferentiated [23].

Based on their habitat, female $A$. bicolor is more dominant in freshwater than estuarine. The male will complete their gametogenesis process in the seawater, resulting in a minor male in freshwater [17]. Observations of $A$. bicolor at various sizes from different habitats showed that the male's body size is smaller than the female [24].

\subsection{Body Composition}

Lipid content becomes loaded for the eel to migrate [5]. The eel stops its feeding activities from obtaining energy from body lipid storage $[17,25]$. When the digestive tract is empty, energy deposits from body fats supply the body's energy need [26]). Increased body lipid levels in eel become increase gonad maturity [27]. Therefore, body lipid levels of eel fish become essential to be studied to see migratory and spawning eel fish's readiness.

Lipid as a precursor of vitellogenin relates to increasing body lipid in the reproductive phase, a source of nutrients for the ovum. It accumulates as an egg yolk in the oocytes increase in size. In vitellogenesis, there is an accumulation of yolk, which is an essential component inside the oocytes. The vitellogenesis phase begins when vitellogenin circulates towards the surface layer of the growing oocyte. Translocation of the cytoplasm forms the yolk's body and the proteolytic cleavage of vitellogenin into a subunit of egg yolk lipoprotein, lipovitellin, and phosvitin. The presence of vitellogenin indicates the accumulation of yolks in the oocytes [28].

Increased body lipid levels in eel fish are needed to prepare gonad maturation, but it is required as energy to migrate [29]. The body lipid content of eel fish needed to promote metamorphosis and gonad maturity is above $28 \%$ [30]. Therefore, mature eel (silver eel) often delays migration to sea waters before enough lipid content [31]. Body lipid of $A$. japonica decreases during migration from freshwater to seawater at spawning [32]. So that the changing patterns of lipid content $A$. bicolor in different environments can be a marker of whether eels obtained were in the process of migrating or indeed live in the neighborhood. Like previous research in A. rostrata and A. japonica, males are found in freshwater, such as females, located in an estuary $[9,15]$.

Energy needs in the process of reproduction of eel as migratory fish is higher than nonmigratory fish. During migrating eel, swim to spawning locations, and there is an increase in gonad maturity, resulting in weight loss and water loss [29, 33]. Energy needs seem to be limiting factors for the eel to succeed in its reproduction process. The eel will accumulate all its energy only for the reproduction process. The type of eel strategy belongs to the semelparous, which sacrifices its survival for the reproduction process. The energy availability in eel is reflected in the body lipid content strongly influenced by distance 
traveled during migration [34]. So that the accumulation of fat content before migration becomes very important for eel fish. Eel fish that migrate will prepare their body lipid levels up to $60-67 \%$ of their body weight $[28,30]$. Although body lipid is the most crucial energy source during migration, the body's protein levels are also necessary to prepare vitellogenin in females [29].

Generally, freshwater and seawater eels had a higher lipid content than brackish water/estuary eels, influenced by the food availability and preparation for spawning [16]. [35] showed three types of A. japonica: seawater eels, estuarine eels, and freshwater eels. Seawater eel never migrates to freshwater during their life history, but they still live at the seawater. Whereas estuarine eel is the eel that always lives in estuaries and freshwater eels spend their life in freshwater and then migrate to the seawater after puberty [35].

Eels will migrate to spawn after reaching puberty (silver eel) from freshwater to seawater so that eels will expose changes in salinity. Morphological and physiological changes [31,36] include body color, head shape, eye diameter, and pectoral fin length [1].

The body lipid content of eel in freshwater, brackish water, or seawater is related to osmoregulation and the need for energy. During migration, eels need the power to regulate osmoregulation related to environmental salinity changes that affect their osmotic concentration [16]. The freshwater eel had higher lipid content than brackish water, and they need high metabolic costs and low accumulated energy stores in their tissues. Therefore, brackish water eel uses more energy to maintain the osmotic concentration of the body [16]. The lower lipid content indicates an increase in energy requirements to maintain homeostasis so that the body's osmotic concentration remains stable [35].

\subsection{Gonadosomatic Index (GSI)}

The GSI value obtained indicates that the $A$. bicolor caught so far is still in the immature stage of the gonad, as in $A$. japonica which has a GSI value of $4.3 \%$ but has reached the pubertal phase [35]. This study proves that eel is not always in freshwater habitats in its growth phase. Generally, the value of male GSI is lower than females [14]. So it is interesting to observe further the dominance of eel in these two habitats. Male eel has lower GSI than females, which indicates that male eel will complete the gametogenesis process in the sea [17] so that in estuarine many male eels are preparing to migrate to the sea. When the female has reached puberty, its body color change to silver eel, an increase in the value of GSI, and body lipid levels more than $20 \%$, they are ready to migrate to the sea to spawn $[5]$.

\section{Conclusions}

Based on the result, it can conclude that the lipid content of freshwater eels was higher than the estuary eel, while another body composition is relatively the same. Lipid is the most energy resource for eel during migration.

\section{Acknowledgement}

We want to thank the LPPM UNSOED for funding this research through the Research Grant (No: Kept .121/UN23.18/PT.01.05/2020). 


\section{References}

1. T. Arai, A. Kotake, T. K. McCarthy, Estuar. Coast. Shelf. Sci. 67 (2006)

2. K. Tsukamoto, S. Chow, T. Otake, H. Kurogi, N. Mochioka, M.J. Miller, J. Aoyama, S. Kimura, S. Watanabe, T. Yoshinaga, A. Shinoda, M. Kuroki, M. Oya, T. Watanabe, K. Hata, S. Ijiri, Y. Kazeto, K. Nomura, H. Tanaka, Nat. Commun. 2, 179 (2011)

3. $\quad$ S. H. Lin, Y. Iizuka, W.N. Tzeng, Zool. Stud. 51 (2012)

4. A. M. Churcher, J.M. Pujolar, M. Milan, P.C. Hubbard, R.S.T. Martins, J.L. Saraiva, M. Huertas, L. Bargelloni, T. Patarnello, I.A.M. Marino, L. Zane, A.V.M. Canário, BMC Genomics, 15, 799 (2014)

5. J. Nowosad, D. Kucharczyk, T.K. Czarkowski, K. Kwasek, Ital. J. Anim. Sci. 13 (2014).

6. A. Cresci, C.B. Paris, C.M.F. Durif, S. Shema, R.M. Bjelland, A.B. Skiftesvik, H.I. Browman, Sci. Adv. 3, 6 (2017)

7. I. J. Chai, T. Arai, J. Appl. Anim. Res. 46, 1108-1113 (2018)

8. P. Laffaille, A. Acou, J. Guillouët, Ecol. Freshw. Fish 14, 191-196 (2005)

9. W. H. Krueger, K. Oliveira, Environ. Biol. Fishes 55, 381-389 (1999)

10. A. Bark, B. Williams, B. Knight, ICES J. Mar. Sci. 64, 1368-1378 (2007)

11. F. Macrì, G. Rapisarda, C. De Stefano, M. De Majo, T. Bottari, G. Aiudi, Journal of Exotic Pet Medicine, 23, 147-151 (2014)

12. F. N. Rachmawati, U. Susilo. Sains Akuatik, 10, 148-154 (2009)

13. F. N. Rachmawati, U. Susilo, Biota, 16, 221-226 (2011)

14. F. N. Rachmawati, U. Susilo, M. Muslih, J. Iktiologi Indones. 17, 155-163 (2017)

15. L. Marohn, E. Jakob, R. Hanel, J. Sea Res, 77, 100-106 (2013)

16. C. Parzanini, M.T. Arts, M. Rohtla, J. Koprivnikar, M. Power, A. B. Skiftesvik, H.I. Browman, D. Milotic, C.M.F. Durif, J. Fish Biol. 99, 1110-1124 (2021).

17. R. Sudo, N. Fukuda, J. Aoyama, K. Tsukamoto, Coast. Mar. Sci. 36, 13-18 (2013).

18. F. W. Tesch. The eel. (John Willey \& Sons, New York, 2008).

19. E. J. Rupia, J. Shen, J. Wu, W. Chen, L. Liu, K. Dierckens, P. Sorgeloos, W. Lu, Aquacult. Int. 22, 1105-1120 (2014).

20. K. Mahmood, Z. Ayub, G. Siddiqui, Indian J. Geomarine Sci. 40, 516-521 (2011)

21. M. J. De Smith, A Comprehensive Handbook of Statistical Concept, Techniques and Software Tools. (The Winchelsea Press, Winchelsea, 2018)

22. T. Arai, S.R.A. Kadir, Sci. Rep. 7, 1 (2017)

23. F. Rachmawati, Y. Sistina, IOP Conf. Ser. Earth and Environ. Sci. 593 (2020)

24. T. Trancart, C. Tudorache, G.E.E.J.M. van den Thillart, A. Acou, A. Carpentier, C. Boinet, G. Gouchet, E. Feunteun. J. Experimental Marine Biology and Ecology, 463 (2015)

25. J. E. Schneider, Physiol. Behav. 81, 289-317 (2004)

26. G. van den Thillart, S. Dufour, J. Cliff Rankin. How to estimate the reproductive success of European silver eels: in spawning migration of the European eel. (Dordrecht, Springer, 2009). 
27. J. B. Cerda, B.G. Calman, G.J. LaFleur Jr, S. Limesand, Gen. Comp. Endocrinol. 103, 24-35 (1996)

28. A. P. Palstra, G.E.E.J.M. van den Thillart, Fish Physiol. Biochem. 36, 297-322 (2010).

29. K. Rousseau, A.G. Lafont, J. Pasquier, G. Mauger, C. Jolly, M.E. Sebert, S. Aroua, C. Pasqualini and S. Dufour, Advances in Eel Reproductive Physiology and Endocrinology. In: F. Trischitta, Y. Takei \& P Sebert (Eds). Eel Physiology (CRC Press. Taylor \& Francis Group, New York, 2014)

30. Durif, C.M.F., Van Ginneken, V., \& Dufour, S. Seasonal evolution and individual differences in silvering eels from a different location. In: G. Van den Thillart, J. Rankin \& S. Dufour (eds) Spawning Migration of the European Eel. (Dordrecht, Springer, 2009)

31. H. Saito, H. Kurogi, S. Chow, N. Mochioka, J. Oleo Sci. 64, 603-16 (2015)

32. A. P. Palstra, D. Crespo, G.E.E.J.M. van den Thillart, J.V. Planas, Am. J. Physiol. Regul. Integr. Comp. Physiol. 299, R486-R499 (2010)

33. M. Gaillard, L. Bernatchez, R. Tremblay, C. Audet, Comp. Biochem. Physiol. A Mol. Integr. Physiol. 188 (2015)

34. P. D. Clevestam, M. Ogonowski, N.B. Sjöberg, H. Wickström, J. Fish Biol. 78 (2011)

35. S. Hagihara, J. Aoyama, D. Limbong, K. Tsukamoto, J. Fish Biol. 97, 6 (2020)

36. A. Kotake, A. Okamura, Y. Yamada, T. Utoh, T. Arai, M.J. Miller, H.P. Oka, K. Tsukamoto, Mar. Ecol. Prog. Ser. 293 (2005) 